\title{
POTENSI ARKEOLOGI PRASEJARAH KABUPATEN TANAH BUMBU DAN ANCAMAN YANG DIHADAPINYA
}

\section{THE POTENCY OF PREHISTORIC ARCHAEOLOGY IN TANAH BUMBU AND ITS THREATENINGS}

\author{
Bambang Sugiyanto \\ Balai Arkeologi Banjarmasin, Jalan Gotong Royong II, RT 03/06, Banjarbaru 70711, Kalimantan Selatan; \\ email: bsugiyanto67@gmail.com
}

\begin{abstract}
Abstrak. Kabupaten Tanah Bumbu merupakan daerah pemekaran baru dari Kabupaten Kotabaru. Kabupaten Tanah Bumbu mempunyai sumber daya kawasan karst yang besar, terutama di wilayah Kecamatan Mantewe. Penelitian arkeologi di Kabupaten Tanah Bumbu dilakukan Balai Arkeologi Banjarmasin sejak tahun 2008. Permasalahan penelitian adalah mengetahui potensi situs arkeologi prasejarah di Kabupaten Tanah Bumbu dan ancamannya. Metode penelitian yang digunakan adalah survei dan ekskavasi arkeologi terhadap gua-gua di kawasan karst Mantewe. Hasil penelitian menunjukkan adanya informasi baru tentang situs gua hunian prasejarah di kawasan tersebut, yaitu adanya lukisan dinding gua dan temuan rangka manusia. Ditemukan juga adanya tiga kegiatan yang mengancam keberadaan situs, yaitu kegiatan penambangan batubara, penambangan batu gamping, dan penambangan guano. Oleh karena itu penelitian lanjutan yang intensif harus segera dilakukan, kawasan karst harus dilindungi dan dikelola dengan baik.
\end{abstract}

Kata kunci: arkeologi prasejarah, kawasan karst Mantewe, Tanah Bumbu, Kalimantan Selatan

\begin{abstract}
Tanah Bumbu Regency is a new enfoldment of Kotabaru Regency. This regency has huge of karsts area, especially in Mantewe District. Archaeological researches of survey and excavation in Tanah Bumbu have been conducted since 2008 by Balai Arkeologi Banjarmasin. The problems will be solved in this article are how high the potency of prehistoric sites and the threatened condition of sites. The methods used were survey and excavation in the karsts region of Mantewe. The results inform the new data of cave settlements which contain rock art and human burial from prehistory. There are also found three activities which harm the cave sites coal mining, limestone mining, and guano collecting. Therefore, it is compulsory to conduct advance researches, to protect the sites by the Heritage Act, and to manage the karsts area effectually.
\end{abstract}

Keywords: prehistoric archaeology, Mantewe karst region, Tanah Bumbu, South Kalimantan

\section{PENDAHULUAN}

Kabupaten Tanah Bumbu merupakan satu dari tiga belas wilayah kabupaten/kota yang baru di Provinsi Kalimantan Selatan. Kabupaten Tanah Bumbu merupakan pemekaran dari Kabupaten Kotabaru, dengan ibukota pemerintahan berada di Batulicin. Salah satu kecamatan yang mempunyai potensi karst adalah Kecamatan Mantewe yang berada di bagian paling utara berbatasan dengan wilayah Kabupaten Kotabaru. Kawasan karst di Kecamatan Mantewe ini berada di wilayah administrasi beberapa desa, seperti Desa Mantewe, Desa Sukadamai, Desa Bulurejo,
Desa Rejosari, dan Desa Dukuhrejo (Sugiyanto 2009: 3-4).

Hasil survei yang dilaksanakan Balai Arkeologi Banjarmasin pada tahun 2006 dan 2008 menunjukkan bahwa terdapat beberapa situs gua dan situs yang diduga pernah dihuni oleh manusia prasejarah ribuan tahun lalu. Dugaan ini didasarkan pada temuan permukaan pada beberapa gua dan situs, seperti sisa-sisa makanan berupa pecahan tulang binatang, cangkang kerang air tawar, dan bekas perapian. Temuan permukaan ini merupakan bukti bahwa pada masa lalu di situs itu pernah ditempati manusia. 
Situs Gua Sugung (Desa Mantewe), Gua Payung/Batu Tanjak (Desa Bulurejo), Gua Harimau (Desa Rejosari), merupakan contoh situs potensial yang diduga pernah dihuni manusia prasejarah masa lalu. Salah satunya sudah rusak karena penggalian guano (kotoran kelelawar) untuk pupuk tanaman. Penggalian guano ini terjadi hampir pada semua kawasan karst di Kecamatan Mantewe. Penduduk sekitar kawasan karst yang membuka lahan pertanian atau perkebunan memerlukan pupuk untuk menyuburkan tanaman mereka. Pilihan pupuk yang murah dan baik adalah kotoran kelelawar yang banyak ditemui pada gua-gua di kawasan karst tersebut.

Data tentang budaya manusia prasejarah yang tinggal di gua dan ceruk di kawasan karst di Kecamatan Mantewe merupakan permasalahan yang sangat menantang untuk diungkapkan. Indikasi hunian manusia prasejarah di Kecamatan Mantewe merupakan informasi kedua setelah ditemukan situs hunian di Kecamatan Muara Uya, Kabupaten Tabalong.

Data penelitian menunjukkan bahwa manusia prasejarah pernah tinggal di dalam gua-gua di kawasan karst Bukit Batu Buli, Desa Randu, Kecamatan Muara Uya, Kabupaten Tabalong. Mereka mengembangkan kehidupan dan kebudayaan prasejarah di dalam Gua Babi, sementara untuk penguburan mereka memilih Gua Tengkorak (gua lain yang berada di balik bukit dari lokasi Gua Babi). Manusia pendukung kebudayaan prasejarah di Gua Babi dan Gua Tengkorak adalah manusia dari ras Austromelanesid berjenis kelamin perempuan. Berdasarkan pengukuran radiokarbon pada kedalaman 70-80 cm (layer b), diketahui bahwa pemukiman gua-gua tersebut mempunyai kronologi $5.050 \pm 100 \mathrm{BP}$ (Widianto dan Handini 2003: 2). Situs Gua Babi dan Gua Tengkorak ini berada di kawasan karst di sisi barat dari Pegunungan Meratus yang membelah Kalimantan Selatan.

Potensi arkeologi di wilayah Kabupaten Tanah Bumbu belum banyak terungkap karena masih terbatasnya pelaksanaan penelitian arkeologi di wilayah ini. Balai Arkeologi Banjarmasin sebagai UPT dari Kementerian Pendidikan dan Kebudayaan, beberapa kali melakukan penelitian survei dan ekskavasi di Kabupaten Tanah Bumbu, baik ketika masih menjadi wilayah Kabupaten Kotabaru maupun sudah menjadi kabupaten sendiri. Potensi arkeologi prasejarah dan sejarah di Kabupaten Tanah Bumbu ada di Kecamatan Mantewe dan Batulicin. Permasalahan yang menarik untuk diajukan dalam artikel ini adalah: bagaimana potensi arkeologi prasejarah di Kabupaten Tanah Bumbu, dan bagaimana ancaman yang dihadapinya?

Sampai tulisan ini dibuat, belum ditemukan lagi situs prasejarah di bagian sisi barat Pegunungan Meratus yang lain. Sisi barat Pegunungan Meratus ini antara lain meliputi Kabupaten Hulu Sungai Tengah, Balangan, Hulu Sungai Selatan, Tapin, dan Banjar. Sementara di sisi timur Pegunungan Meratus yang meliputi Kabupaten Kota Baru dan Tanah Bumbu diduga mempunyai potensi kawasan karst yang sama. Kawasan karst ini banyak dijumpai di sekitar Kecamatan Mantewe, Simpang Empat, Sungai Kupang (Kabupaten Tanah Bumbu), Hampang dan Sungai Durian (Kabupaten Kotabaru).

\section{METODE}

Permasalahan di atas akan dijawab dengan menggunakan metode penelitian eksploratif deskriptif, yang dilakukan dengan kegiatan survei lapangan dan ditindaklanjuti dengan ekskavasi arkeologi pada beberapa situs arkeologi yang terpilih. Pelaksanaan survei dilakukan pada kawasan karst di wilayah Kabupaten Tanah Bumbu, difokuskan di Kecamatan Mantewe. Survei inventarisasi situs gua dan ceruk prasejarah ini kemudian ditindaklanjuti dengan pelaksanaan penelitian ekskavasi (penggalian) terutama pada situs-situs yang diduga sebagai hunian manusia prasejarah, seperti Gua Payung Gua Batu Tanjak, Gua Sugung, dan Liang Bangkai.

\section{HASIL DAN PEMBAHASAN}

\section{Potensi Arkeologi Prasejarah di Kabupaten Tanah Bumbu}

Wilayah Kabupaten Tanah Bumbu, secara umum terdiri atas 10 kecamatan, yaitu: Kecamatan 


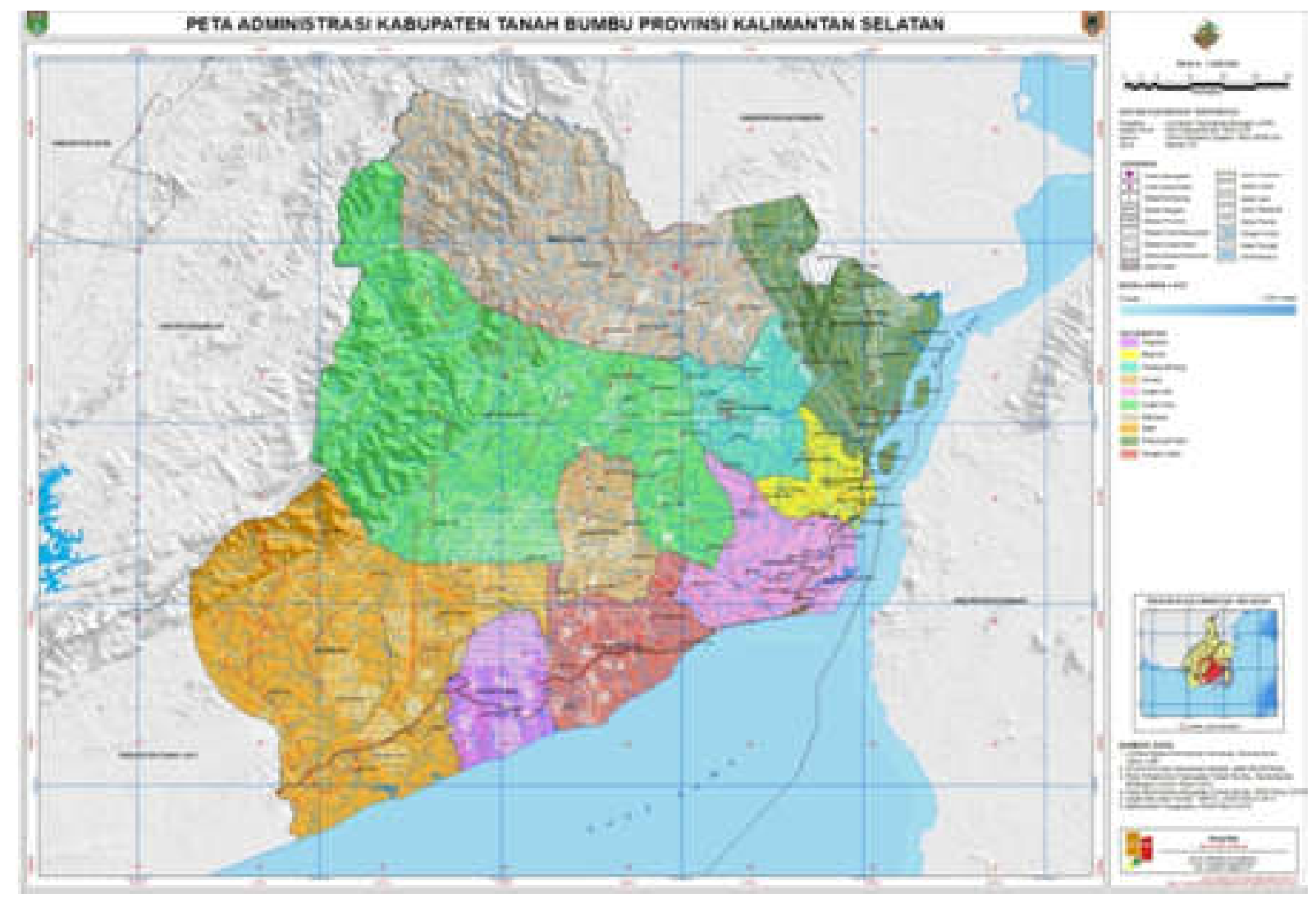

sumber: desainmap.com

Gambar 1. Peta Kabupaten Tanah Bumbu dan potensi kawasan karst.

Batulicin, Simpang Empat, Karang Bintang, Mantewe, Kusan Hulu, Satui, Angsana, Sei Loban, Kuranyi, dan Kusan Hilir. Berdasarkan peta administrasi di atas, tampak bahwa deretan pegunungan berada di wilayah Kecamatan Simpang Empat, Mantewe, Kusan Hulu, dan Satui.

Pegunungan dan perbukitan yang ada di Kecamatan Mantewe, Kusan Hulu, dan Satui, berada di jajaran Pegunungan Meratus pada sisi bagian timur selatan (tenggara). Survei arkeologi yang dilaksanakan di wilayah Kecamatan Mantewe pada tahun 2006, memperlihatkan besarnya potensi kawasan karst yang ada. Survei dilakukan di tiga desa, yaitu Desa Mantewe, Rejosari, dan Bulurejo, dan berhasil menemukan situs-situs prasejarah, seperti Gua Sugung, Gua Landung, dan Gua Pembicaraan (Desa Mantewe), Gua Harimau (Desa Rejosari), dan Gua Payung/ Batu Tanjak (Desa Bulurejo). Kelima situs gua di atas secara morfologis memenuhi syarat layak huni.
Manusia prasejarah mempunyai banyak pertimbangan dalam menentukan dan memilih gua atau ceruk yang dipilih sebagai tempat hunian. Secara umum di Indonesia, kehidupan manusia prasejarah di dalam gua-gua mulai dikenal sekitar 10.000 tahun lalu. Hasil penelitian arkeologi pada beberapa situs gua hunian di Jawa, Sumatera, dan Sulawesi memperlihatkan kronologi yang sama, meskipun ada juga situs gua hunian yang mempunyai kronologi lebih tua dari 10.000 tahun lalu. Morfologi gua atau ceruk yang layak dipilih sebagai tempat hunian adalah gua dan ceruk yang memenuhi beberapa persyaratan penting.

Syarat pertama, gua atau ceruk yang mempunyai ukuran cukup lebar. Ukuran yang cukup luas inilah yang memungkinkan manusia dapat melaksanakan semua kegiatan kehidupan sehari-hari di dalam gua atau ceruk.

Syarat kedua, gua dan ceruk harus mempunyai kondisi permukaan tanah yang kering 


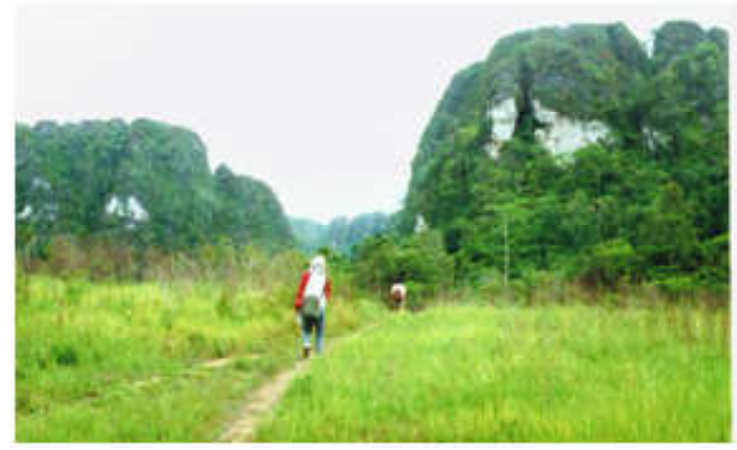

dok. Balar Banjarmasin

Gambar 2. Perjalanan survei menyelusuri perbukitan karst yang ada di Desa Mantewe.

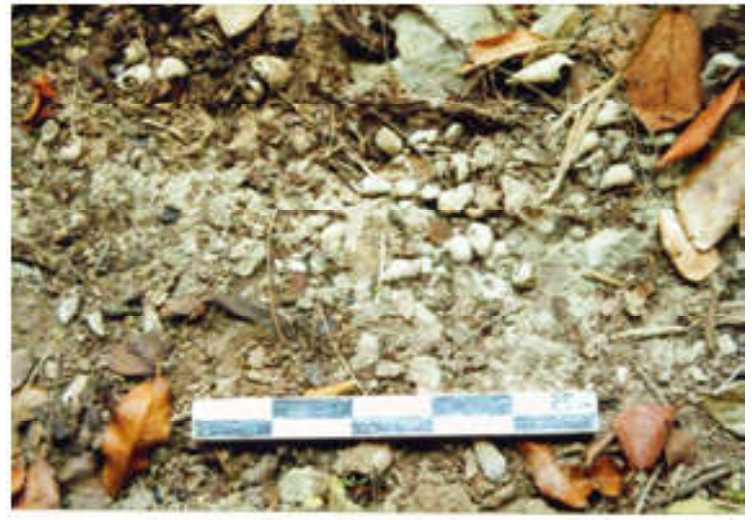

sumber: dok. Balar Banjarmasin

Gambar 3. Sisa makanan berupa cangkang kerang (sehe atau ketuyung dalam bahasa Banjar).

dan rata, serta mempunyai sirkulasi udara yang segar dan nyaman. Permukaan tanah yang kering akan memudahkan terlaksananya semua kegiatan kehidupan di dalam gua, didukung dengan udara yang segar tidak pengap atau bau. Bau yang tidak sedap (pengap) seringkali terjadi di dalam gua atau ceruk, apalagi jika gua itu dimanfaatkan sebagai rumah oleh binatang, misalnya kelelawar.

Syarat ketiga, mempunyai intensitas cahaya yang cukup. Artinya gua atau ceruk itu harus terang tidak gelap. Syarat keempat yang paling penting adalah keletakkannya yang dekat dengan sumber air, seperti sungai, danau, telaga, atau lainnya. Lokasi gua yang dekat dengan sumber air akan menjamin kelangsungan kehidupan kelompok manusia yang tinggal di dalamnya. Keempat syarat inilah yang sering digunakan untuk mencari dan menemukan situs prasejarah, terutama guagua atau ceruk hunian di kawasan karst.

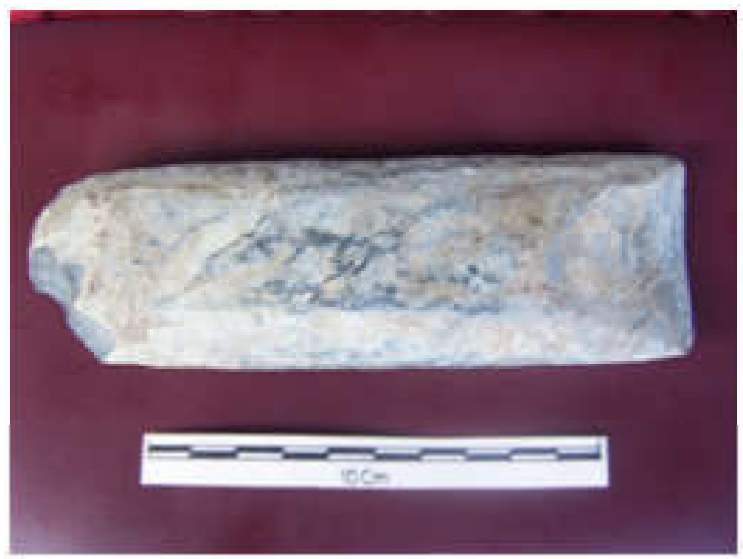

sumber: dok. Balar Banjarmasin

Gambar 4. Temuan beliung persegi dari Gua Pembicaraan.

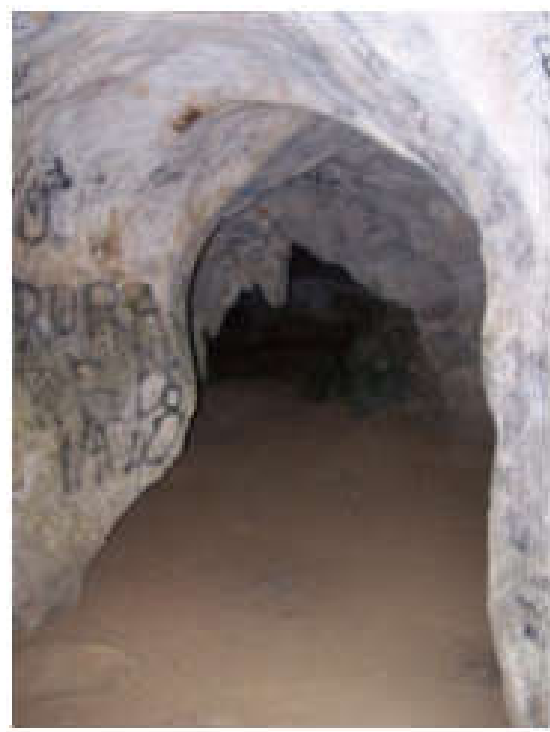

sumber: dok. Balar Banjarmasin

Gambar 5. Kondisi Gua Payung tahun 2006, permukaan tanahnya rata dan kering.

Di Kecamatan Mantewe, penelusuran gua dan ceruk dilakukan dengan pengamatan langsung pada pegunungan atau perbukitan karst. Gua Sugung misalnya, merupakan sebuah gua yang mempunyai muara (pintu) gua yang cukup besar dan lorong gua yang panjang. Berdasarkan penjelasan tentang syarat layak huni di atas, maka dapat dipastikan bahwa kehidupan manusia di dalam gua atau ceruk hanya akan berada di bagian muara gua yang terang. Ruangan gua yang gelap biasanya hanya dimanfaatkan sebagai tempat ritual atau tempat penguburan. 
Muara Gua Sugung yang kering dengan permukaan tanah yang relatif rata, sangat memungkinkan untuk melaksanakan kegiatan kehidupan. Indikasi yang menguatkan jika Gua Sugung ini pernah dimanfaatkan oleh manusia prasejarah adalah adanya temuan artefaktual berupa sisa-sisa makanan seperti pecahan tulang binatang dan cangkang kerang, pecahan batu sebagai sisa-sisa pembuatan alat batu, dan bekas perapian yang pernah dibuat. Inilah yang membuat Gua Sugung dapat disimpulkan sebagai situs yang diduga pernah dihuni oleh manusia prasejarah pada masa lalu. Cangkang kerang dalam bahasa Banjar disebut dengan sehe dan katuyung. Jenis kerang yang ditemukan di Gua Sugung saat ini masih dapat ditemukan di sungai kecil yang ada di depannya.

Situs lainnya adalah Gua Landung dan Gua Pembicaraan, yang berada di deretan pegunungan karst yang sama dengan Gua Sugung. Lokasi Gua Landung dan Gua Pembicaraan cukup jauh dari Gua Sugung, melalui jalan setapak menyusuri pegunungan karst di Desa Mantewe ke arah utara. Secara morfologis, Gua Landung mempunyai kondisi tanah yang kering, sirkulasi udara baik, hanya permukaan tanahnya agak melereng tidak rata. Beberapa pecahan batu dan cangkang kerang ditemukan di dalamnya.

Demikian juga dengan Gua Pembicaraan, yang letaknya paling jauh di antara ketiga situs gua di atas, dan ada temuan sebuah beliung persegi yang cukup besar di dalamnya. Situs lain yang sempat dikunjungi di tahun 2006 itu adalah sebuah gua yang berada di sebuah bukit karst tunggal di batas Desa Bulurejo (dekat jembatan yang menghubungkan ke Desa Sukadamai). Guagua tersebut secara morfologis sangat memenuhi syarat layak huni, mempunyai ruangan yang cukup luas, kondisi permukaan tanah di dalam gua kering, sirkulasi udaranya bagus tidak lembab dan pengap, lokasi gua berdekatan dengan sumber air, dan yang paling penting adanya temuan permukaan di dalam gua berupa sisa- sisa makanan dan serpihan batu sisa pengerjaan alat batu.

Hasil percobaan lubang uji (test pit) di Gua Sugung dan Gua Payung, menemukan sejumlah artefak hasil kebudayaan manusia prasejarah. Hasil budaya prasejarah itu berupa serpih bilah, fragmen gerabah, perhiasan batu, dan sisa makanan seperti fragmen tulang binatang serta cangkang kerang. Artefaktual tersebut jelas membuktikan bahwa Gua Sugung dan Gua Payung pernah digunakan sebagai hunian manusia prasejarah pada masa lalu (Sugiyanto 2009: 4).

Satu gugus bukit karst di wilayah Desa Dukuhrejo, menjadi fokus penelitian arkeologi prasejarah adalah Bukit Bangkai. Bukit Bangkai merupakan satu gugus bukit karst yang berdiri sendiri dengan menyimpan banyak gua dan ceruk di dalamnya. Masyarakat Desa Dukuhrejo sudah lama mengenal gua-gua ini, bahkan sudah menjadikan Bukit Bangkai sebagai tempat wisata lokal yang sering dikunjungi terutama oleh pramuka dan anak-anak sekolah menengah saat liburan. Hasil penelitian survei yang dilakukan tim peneliti Balai Arkeologi Banjarmasin sejak tahun 2010, menunjukkan bahwa Bukit Bangkai mempunyai potensi arkeologi prasejarah yang sangat baik. Hasil pengamatan bentuk dan morfologi gua dan ceruk, yang didukung dengan temuan permukaan, menunjukkan sedikitnya terdapat 22 situs yang diduga pernah dihuni oleh manusia prasejarah pada masa lalu (Sugiyanto dkk. 2013: 23) ${ }^{1}$.

Tiga situs di Bukit Bangkai sudah diteliti secara cermat, melalui penggalian arkeologi. Ketiga situs itu adalah Liang Bangkai 1, Liang Bangkai 10, dan Ceruk Bangkai 3. Hasil penggalian menunjukkan bahwa situs Liang Bangkai 1 difungsikan sebagai tempat tinggal oleh manusia prasejarah. Mereka tinggal di dalam Liang Bangkai 1 dengan mengembangkan budaya alat batu serpih bilah, membuat alat dari bahan tulang (lancipan tulang), mengkonsumsi daging binatang buruan dan sumber makanan lain

Penelitian situs-situs prasejarah di kawasan karst di Kecamatan Mantewe ini dilakukan dua tahun sekali mulai tahun 2008, 2010, dan 2012. Kemudian sejak tahun 2013 dilakukan tiap tahun dengan penekanan pada budaya prasejarah di Pegunungan Meratus bagian Selatan, yang meliputi wilayah Kabupaten Tanah Bumbu dan Kotabaru daratan. 
yang dapat diambil dari lingkungan sekitar gua. Sumber makanan alternatif ini biasanya terdiri dari jenis kerang-kerangan, ikan-ikan, dan udang yang banyak dijumpai di sungai dan rawa-rawa yang ada di sekitarnya (Sugiyanto dkk. 2013: 22). Selain itu pada tahapan kehidupan yang lebih muda, mereka juga sudah bisa membuat wadah makanan dari tanah liat bakar (gerabah). Gerabah ini mereka buat dengan teknologi khusus dan teknik pembakaran yang baik.

Hasil pengamatan bentuk terhadap serpihan batu yang berhasil dikumpulkan sejak tahun 2010 di Liang Bangkai 1, menunjukkan teknologi pembuatan alat batu di situs ini bercirikan serpih bilah yang mempunyai ujung meruncing. Apabila didasarkan pada bentuk alat, maka temuan serpihan batu dari Liang Bangkai 1 dapat digolongkan dalam beberapa kelompok, yaitu:

1. Kelompok serpih

2. Kelompok bilah

3. Kelompok batu inti

4. Kelompok serpih dipangkas (radial core)

5. Kelompok serpih diretus

6. Kelompok bilah diretus

7. Kelompok alat batu masif

8. Kelompok batu pemukul (hammer)

Bahan batuan yang digunakan dalam pembuatan alat batu di situs Liang Bangkai 1 cukup beragam, antara lain terdiri atas gamping kersikan (rijang), chert, kalsedon, jasper, dan andesit. Di antara jenis batuan di atas, chert, dan gamping kersikan (rijang), merupakan bahan batuan yang paling banyak digunakan. Jenis batuan chert yang digunakan pada umumnya mempunyai tekstur halus dan berwarna kekuningan, coklat tua, coklat kemerahan, abuabu kecoklatan, dan hitam. Batuan ini pada umumnya memiliki kandungan silika tinggi, terutama yang berwarna coklat kemerahan dan semi transparans. Chert dan gamping kersikan (rijang) mudah didapatkan di sekitar situs Liang Bangkai 1 (Sugiyanto dkk. 2013: 15).

Temuan alat batu di situs Liang Bangkai 1 terdiri dari alat masif dan alat serpih. Alat masif yang ditemukan berupa kapak perimbas (chopper), kapak penetak (chopping tool), dan batu pukul (hammer stones). Jenis alat masif ini sebagian besar ditemukan pada lapisan atas dan permukaan, sementara temuan alat serpih (flakes) merupakan temuan yang paling dominan.

Pada umumnya alat serpih yang ditemukan di situs Liang Bangkai 1, memiliki faset-faset pada bagian dorsal dan cenderung diserpih ulang. Bentuk alat serpih yang ditemukan terdiri dari berbagai jenis serut, lancipan, dan gurdi. Selain itu, juga ditemukan beberapa batu pukul (hammer stones) yang berasal dari batuan kerakal andesit, dan beberapa batu inti (core) dalam berbagai ukuran.

Menurut Semenov, dalam kehidupan prasejarah, suatu kemampuan teknologi secara tidak langsung mencerminkan hubungan yang aktif antara manusia dengan lingkungan fisik di mana mereka tinggal (Semeno 1964: 1). Sementara James Deetz berpendapat bahwa hasil teknologi juga dapat merefleksikan suatu kemampuan dan ketrampilan, serta ide atau gagasan pelaku dalam menciptakan suatu benda. Hali itu dibuktikan melalui berbagai macam wujud dari tinggalan budaya materi (artefak) yang dihasilkan oleh teknologi. Konsepsi tersebut dilandasi adanya pemikiran bahwa dalam menciptakan suatu benda (artefak), seorang pelaku pasti mempunyai konsep atau rencana tentang bentuk, jenis, dan fungsi dari benda yang diciptakan (Deetz 1967: 45-46).

Secara konseptual pengertian teknologi mencakup dua aspek pokok, yaitu metode dan teknik. Metode diartikan sebagai suatu kebiasaan yang dianggap logis dan teratur dalam pola pikir manusia, sedangkan teknik merupakan suatu bentuk tindakan nyata dari metode yang berkaitan dengan kemampuan manusia dalam mengolah materi tertentu sehingga menghasilkan suatu benda (Crabtree 1972: 2).

Dalam hal teknologi alat batu prasejarah, Indonesia memiliki perkembangan yang identik dengan perkembangan teknologi alat batu secara umum, yaitu dari bentuk sederhana menuju ke bentuk yang lebih kompleks dan sempurna. Proses perkembangan tersebut merupakan proses evolusi teknologis yang cukup panjang yang terbagi dalam tiga masa, yaitu Paleolitik (batu tua), Mesolitik (batu madya), dan Neolitik (batu muda). Di sisi yang lain, perkembangan 


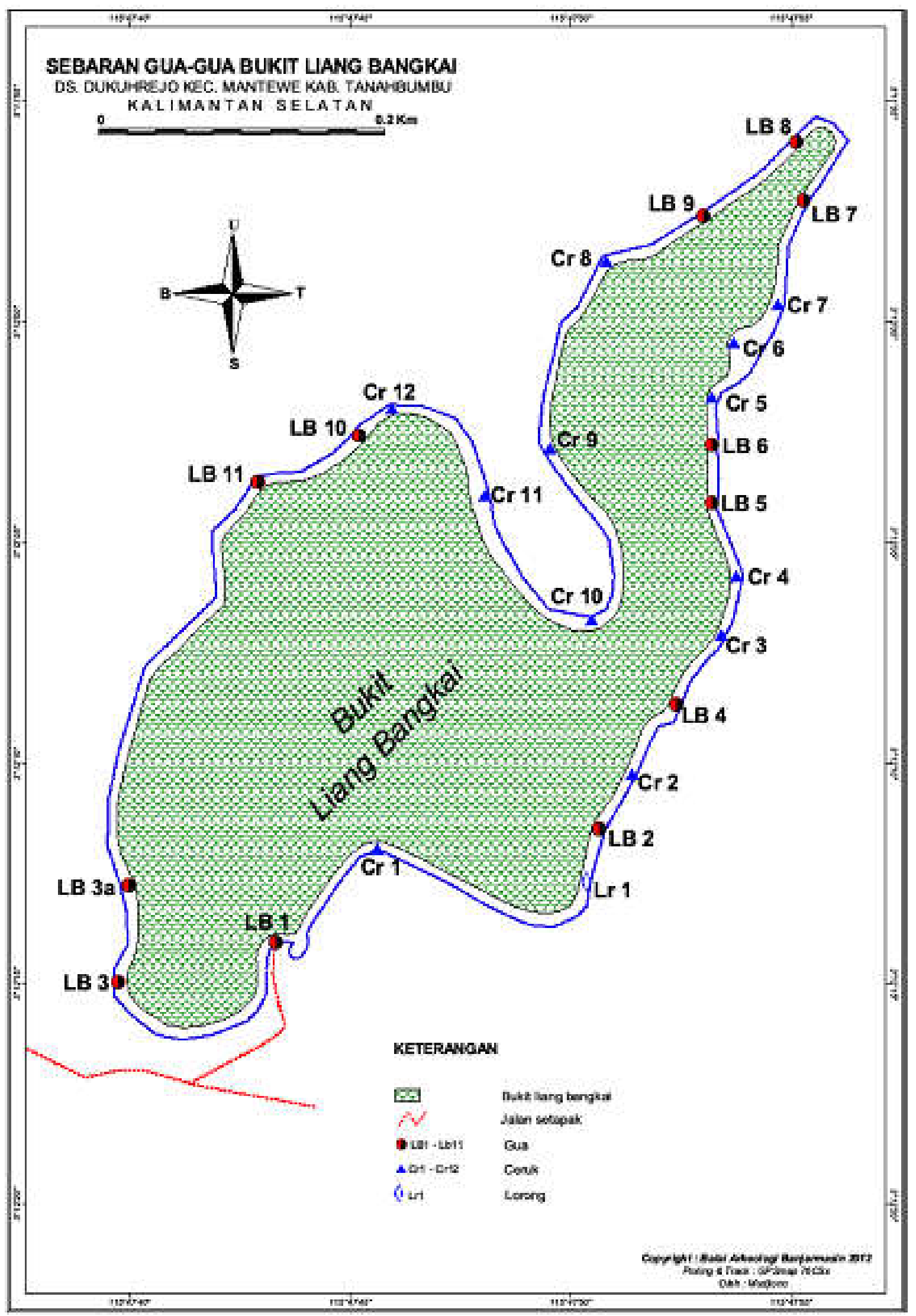

sumber: dok. Balar Banjarmasin

Gambar 6. Peta sebaran situs gua dan ceruk hunian prasejarah di Bukit Bangkai, Desa Dukuhrejo, Kecamatan Mantewe, Kabupaten Tanah Bumbu. 
teknologis tersebut juga memperlihatkan ciri budaya manusia. Teknologi paleolitik berkembang pada pola hidup manusia yang masih mengembara. Teknologi mesolitik berkembang pada kehidupan di dalam gua-gua, sedangkan teknologi neolitik berkembang pesat pada pola hidup pertanian (bercocok tanam).

Selain situs-situs yang berada di Bukit Bangkai, secara khusus tim peneliti Balai Arkeologi Banjarmasin juga mengadakan penelitian ekskavasi di situs Gua Payung di Desa Bulurejo tahun 2012. Tujuannya untuk menemukan situs yang sejaman dengan budaya yang hampir sama dengan yang ditemukan di Liang Bangkai (Desa Dukuhrejo). Sayangnya, pada saat ini kondisi Gua Payung sudah mengalami perubahan. Seiring dengan maraknya perkebunan kelapa sawit, maka Gua Payung ini menjadi korban dari ketidaktahuan masyarakat sekitar tentang kandungan sejarah budaya yang ada di dalamnya. Kandungan sejarah budaya ini terendapkan dalam lapisan tanah yang hanya sedikit yang terdapat di Gua Payung. Keperluan pupuk yang besar untuk memelihara tanaman kelapa sawit, yang membuat tanah-tanah di dalam Gua Payung diambil secara besar-besaran. Kondisi gua hanya menyisakan sedikit lapisan tanah. Hasil penelitian di situs ini tidak bisa maksimal, tetapi masih menemukan cangkang kerang yang bisa dianalisis dengan metode radiacarbon dating, dan menghasilkan angka untuk umur budaya di situs ini, yaitu untuk layer (lapisan

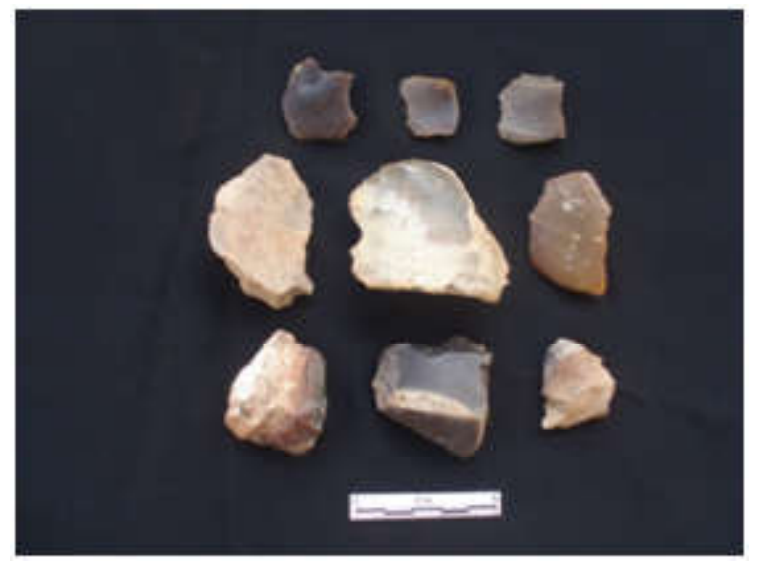

sumber: dok. Balar Banjarmasin

Gambar 7. Kelompok alat batu tipe serpih di Liang Bangkai 1. budaya) $2=2.970 \pm 130 \mathrm{BP}$, dan untuk layer $3=$ $3.030 \pm 130$ BP (Fajari dan Kusmartono 2013: 2023).

Kebudayaan prasejarah di gua-gua yang ada di kawasan karst di Kecamatan Mantewe berkembang pada kisaran waktu 12.000 - 3.000 tahun lalu. Mereka mengembangkan teknik berburu binatang sebagai mata pencaharian yang utama. Kegiatan berburu dilakukan oleh kelompok laki-laki, sementara kelompok ibu dan anak-anak tinggal di dalam gua meramu daun-daunan, buahbuahan, dan biji-bijian dari hutan kecil di sekitar gua tempat tinggal mereka. Selain itu, mereka juga mencari dan menangkap sumber makanan lain yang banyak terdapat di sungai atau rawarawa seperti beberapa jenis ikan dan udang serta berbagai jenis kerang air tawar lainnya. Kerang

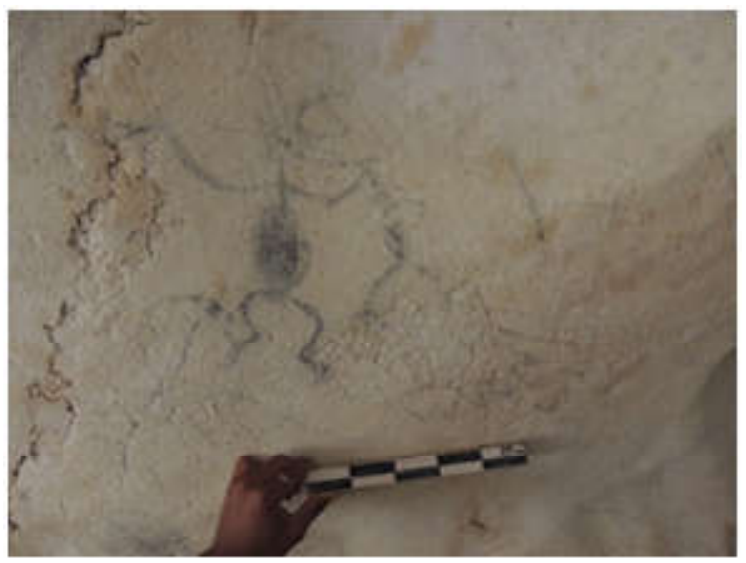

sumber: dok. Balar Banjarmasin

Gambar 8. Salah satu lukisan dinding di Liang Bangkai 1 dengan motif manusia kangkang.

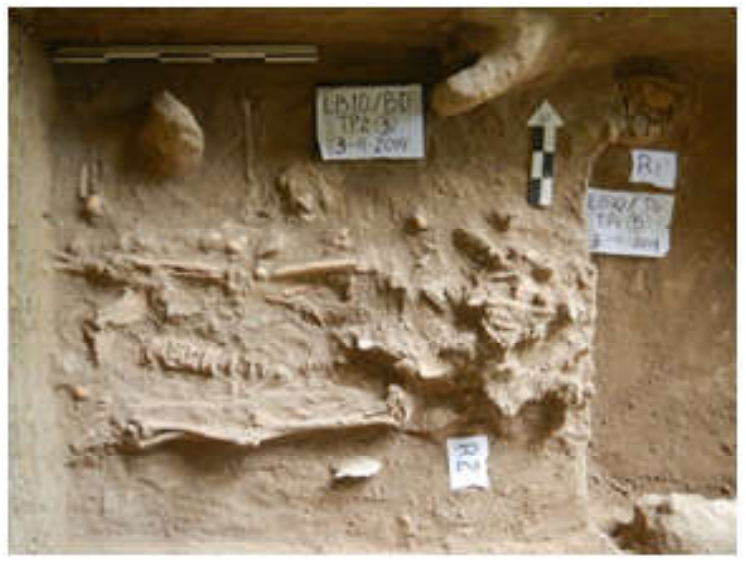

sumber: dok. Balar Banjarmasin

Gambar 9. Temuan sisa penguburan di Liang Bangkai 10 yang terdiri dari dua individu manusia. 
air tawar merupakan sumber bahan makanan yang paling mudah didapatkan, sehingga di dalam guagua akan menjadi ekofak yang paling sering ditemukan setelah alat batu (Sugiyanto dkk. 2014: 45).

Pada tahapan berikutnya, temuan sisa-sisa pembakaran yang terdapat pada fragmen tulang, cangkang kerang dan serpih batu menunjukkan kemampuan membuat api yang dimiliki penghuni Liang Bangkai 1. Penemuan api membuat perkembangan yang begitu cepat terhadap kehidupan manusia prasejarah. Umur kehidupan meningkat, karena asupan makanan yang lebih baik. Di samping membuat teknologi pengolahan makanan jadi semakin baik, pemanfaatan api juga membuat teknologi manusia meningkat tajam. Mereka bisa membuat wadah makanan dari tanah liat yang dibakar.

Pemanfaatan api ini juga mendorong munculnya perasaan atau seni dalam kehidupan manusia prasejarah. Bukti munculnya seni itu antara lain dapat dilihat pada lukisan dinding gua yang ada di Bukit Bangkai dan beberapa gua lain di sekitar perkebunan kelapa sawit di Desa Sukadamai (Sugiyanto dkk. 2014: 41-43). Lukisan dinding gua yang ada di sini semuanya dilukiskan dengan warna hitam. Melihat bentuknya tampak digambarkan dengan menggunakan bantuan alat khusus (semacam kuas kecil). Lukisan dinding gua itu ditemukan di dua buah ceruk kecil di Liang Bangkai 1, Ceruk Bangkai 1a, dan Ceruk Bangkai 12, dan beberapa gua di wilayah Sukadamai (Oktrivia dkk. 2013: 10). Motif yang digambarkan antara lain, motif manusia, binatang, perahu, dan motif lainnya yang kurang jelas. Motif manusia kangkang merupakan motif yang sangat sering ditemukan dalam situs-situs prasejarah lainnya, terutama yang berkaitan dengan budaya megalitik.

Temuan sisa penguburan manusia prasejarah di Liang Bangkai 10 merupakan bukti kehadiran manusia prasejarah ribuan tahun lalu. Sisa penguburan di Liang Bangkai 10 dikuburkan secara langsung (primer) dengan posisi terlentang lurus. Posisi kubur yang seperti ini merupakan kebiasaan yang dibawa oleh kelompok manusia Mongolid, sementara Austromelanesid biasanya melakukan penguburan dengan posisi terlipat (Sugiyanto dkk. 2014: 43-44).
Untuk Kalimantan Selatan, temuan manusia ini merupakan temuan yang kedua setelah temuan sisa penguburan di Gua Tengkorak (Kabupaten Tabalong). Manusia di Gua Tengkorak dikuburkan dengan posisi terlipat miring, dan berdasarkan pengamatan anatomis, diketahui sebagai individu wanita berumur 40-60 tahun (Widianto dan Handini 2003: 48). Posisi penguburan telentang menunjukkan bahwa rangka manusia di Liang Bangkai 10 mempunyai kecenderungan yang kuat sebagai kelompok Mongolid. Jadi ada dua kelompok manusia prasejarah di Kalimantan Selatan yaitu Austromelanesid di utara dan Mongolid di selatan.

Periode hunian yang ditunjukkan dari situs Gua Babi dan Gua Tengkorak di Tabalong, sekitar 6.000 tahun lalu. Menurut Harry Widianto, periode tersebut merupakan "periode kritis" pemunculan dan persebaran ras manusia di Nusantara, dalam kaitannya dengan aspek fisik dan geografis. Lokasi Gua Babi di Kalimantan Selatan merupakan "daerah rawan" bagi distribusi ras Australomelanesid (yang tersebar di Indonesia bagian barat dan selatan), dan ras Mongolid (menyebar di Indonesia bagian uatar dan timur), sejak pemunculan mereka pertama kali pada sekitar 10.000 tahun silam (Jacob 1967 dalam Widianto dan Handini 2003: 4).

Apabila akhir glasiasi terakhir sekitar 11.000 tahun silam disepakati sebagai batas paling awal dari terminologi Pasca Plestosen, maka periode ini sebenarnya merupakan periode kritis yang sangat penting artinya bagi asal mula kolonisasi Nusantara. Alasan pertama, pada masa inilah air laut telah naik kembali hingga sekarang. Kenaikan permukaan air laut ini menyebabkan pemisahan paling akhir daerah kepulauan Nusantara dengan Asia Tenggara Daratan. Alasan kedua, telah terjadi perubahan lingkungan secara global dengan tenggelamnya Paparan Sunda, sehingga menyebabkan pergerakan kembali fauna dalam lingkungan insuler. Alasan ketiga, munculnya Homo sapiens yang dikenal sebagai ras Australomelanesid yang hampir serentak menempati berbagai tempat di kepulauan Nusantara.

Migrasi ras Australomelanesid diduga bermula pada 10.000 tahun silam dari daratan Asia 
Tenggara ke arah selatan dan bagian barat Nusantara. Pergerakan ini dibuktikan dengan berbagai temuan sisa rangka manusia, dan bukti budayanya di Vietnam, Thailand, dan Indonesia bagian barat serta selatan. Data terakhir yang ditemukan di situs Song Keplek dan Gua Braholo di kawasan karst Gunung Sewu menunjukkan okupasi jenis ras ini pada kurun waktu antara 6.000 hingga 10.000 tahun yang lalu (Handini dan Harry Widianto 1998: 3-5). Sebaran ini berlanjut ke daerah timur di Nusa Tenggara, yang kemudian menurunkan ras Australoid saat ini (Widianto dan Handini 2003: 61).

Pada saat yang bersamaan, ras Mongolid yang pertama juga mengikuti gelombang migrasi dari utara, menuju ke Sulawesi dengan melalui Filipina. Sisa manusia dari situs Leang Cadang (Sulawesi Selatan) masuk dalam jalur migrasi ini, yang akhimya bergerak ke timur mulai pulau-pulau utara Indonesia Timur ke Mikronesia dan seterusnya. Pemisahan jenis ras ini cukup signifikan, ras Australomelanesid mengokupasi bagian utara dan barat, sementara ras Mongolid menyebar di daerah Indonesia timur dan utara.

Pada masa yang kemudian, sekitar 6.000 tahun silam pada tingkatan Mesolitik, terjadi gelombang migrasi ras Mongolid, yang akhirnya menghasilkan populasi aktual saat ini (Jacob 1967 dalam Widianto dan Handini 2003: 61). Bagaimana dengan periode penghunian manusia prasejarah di Kalimantan khususnya Kalimantan Selatan?

Berdasarkan pengamatan geografis, letak situs-situs hunian manusia prasejarah di Kalimantan Selatan pada umumnya berada pada kawasan karst di sekitar Pegunungan Meratus. Pulau Kalimantan sebenarnya berada di tengah di antara dua daerah sebaran manusia prasejarah di kepulauan Nusantara. Pendukung budaya prasejarah di kawasan ini, di situs Gua Babi dan Gua Tengkorak atau situs Liang Bangkai dan lainnya di kawasan karst Mantewe, bisa salah satu dari kedua ras di atas atau merupakan percampuran kedua ras tersebut.

Tampaknya peluang ras Australomelanesid untuk mengokupasi kawasan karst Gunung Batubuli sangat kecil kemungkinannya, mengingat lokasi pulau Kalimantan terhadap Asia Tenggara Daratan sebagai daerah asal kedua ras jauh lebih mudah dicapai dari daerah utara, melalui rangkaian pulau-pulau di Philipina. Jika melalui jalur barat dan selatan, ras Australomelanesid akan melalui Sumatera, Jawa, dan harus menyeberangi Laut Jawa yang cukup luas dan tinggi tingkat kesulitannya. Kenyataannya, di situs Gua Tengkorak, ras Australomenesid berhasil mencapai dan mengokupasi gua-gua di kawasan karst Gunung Batubuli, Tabalong, Kalimantan Selatan. Ras Australomelanesid termasuk dalam takson Homo sapiens, merupakan jenis manusia yang benar-benar tangguh dalam menyikapi lingkungannya.

Ini berarti bahwa, meskipun sebaran utama ras Australomelanesid pada periode Pasca Plestosen yang selaras dengan tradisi penghunian gua-gua prasejarah adalah Indonesia bagian barat dan selatan, tidak menutup kemungkinan terdapat kelompok-kelompok kecil ras ini yang telah mencapai Indonesia bagian tengah di Kalimantan Selatan. Bahkan pada periode ini telah terjadi kohabitasi antara ras Australomelanesid dan Mongolid di situs Song Keplek maupun percampuran keduanya yang terlihat pada manusia Wadjak (Handini dan Widianto 1998: 87).

Oleh karena itu, eksistensi ras Australomelanesid dan Mongolid dalam mekanisme hunian gua-gua prasejarah di Kalimantan Selatan merupakan data baru yang kehadirannya diakibatkan oleh "percabangan minor" dari arus migrasi utama mereka. Seperti halnya kerabat mereka di Jawa, tradisi penguburan primer baik terlipat atau telentang secara konsisten tetap dipraktekkan di situs Gua Tengkorak dan Liang Bangkai 10.

Data arkeologi prasejarah yang ada di kawasan karst Mantewe, merupakan satu himpunan situs gua hunian masa prasejarah yang penting bagi sejarah perkembangan kebudayaan manusia di Kalimantan Selatan. Selain menemukan lokasi hunian masa prasejarah, pada situs Gua Sugung, Gua Payung, Liang Ulin, dan gua-gua di Bukit Bangkai, juga terdapat peninggalan "kesenian" berupa gambar-gambar dengan warna hitam pada dinding gua. Kehadiran gambar-gambar ini merefleksikan konsep 
kepercayaan dan cipta rasa yang dimiliki manusia prasejarah pada masa itu.

Gambar-gambar pada dinding gua atau yang lebih dikenal dengan rock-art, selama ini banyak diketahui ada di gua-gua di Indonesia bagian timur. Khusus untuk wilayah Kalimantan, temuan gambar-gambar pada dinding gua baru diketahui sekitar tahun 1988 dengan temuan gambar dinding di Liang Kaung, Kabupaten Putussibau, Kalimantan Barat. Kemudian sekitar tahun 1994, ditemukan gambar dinding gua berupa cap-cap tangan pada Gua Mardua, di Kalimantan Timur. Selanjutnya mulai banyak ditemukan situs gua yang mempunyai gambar dinding di Kalimantan Timur, yaitu pada kawasan karst SangkulirangMangkalihat.

Khusus wilayah Kalimantan Selatan, budaya gambar dinding gua hanya ditemukan di gua-gua yang ada di wilayah Kabupaten Tanah Bumbu dan Kotabaru. Kemungkinan besar di kawasan karst lainnya ada, hanya belum diketahui saja keberadaannya.

Luas kawasan karst di Kecamatan Mantewe hanya sebagian kecil saja dari semua kawasan karst yang ada di Kabupaten Tanah Bumbu, tetapi potensi arkeologi prasejarah yang ada di dalamnya sangatlah besar. Potensi arkeologi prasejarah ini sangat penting bagi sejarah kehidupan dan perkembangan ilmu pengetahuan manusia pada umumnya. Khusus peninggalan prasejarah yang ada di Bukit Bangkai di Desa Dukuhrejo, mempunyai nilai yang lebih baik jika dibandingkan dengan situs prasejarah lainnya di Kecamatan Mantewe. Pada satu gugus bukit karst Bukit Bangkai, terdapat semua temuan dan bukti kehadiran manusia prasejarah, mulai dari temuan materi budayanya sampai pada sisa rangka manusianya. Temuan sisa rangka manusia prasejarah biasanya merupakan bukti pelaksanaan kegiatan penguburan yang pernah dilakukan pada masa lalu.

Berdasarkan temuan artefak, ekofak, dan sisa rangka manusia di beberapa gua di Bukit Bangkai, sudah seharusnya Pemerintah Kabupaten Tanah Bumbu memberikan perhatian yang lebih baik terhadap kelestarian dan keamanan Bukit Bangkai. Bukit Bangkai sudah cukup lama dijadikan sebagai tempat wisata yang cukup ramai.
Pengembangan tempat wisata ini perlu lebih diperhatikan karena adanya situs arkeologi prasejarah yang ada di dalam Bukit Bangkai. Kegiatan wisata penelusuran gua-gua yang sering dilakukan di Bukit Bangkai selama ini bisa tetap berjalan, hanya ada penambahan informasi dan rambu-rambu khusus terutama pada situs-situs gua dan ceruk yang mengandung artefak arkeologi di dalamnya.

Pada rencana kegiatan wisata penelusuran gua-gua di Bukit Bangkai, dapat dibuatkan dua skema perjalanan. Pertama penelusuran gua-gua alam yang menawarkan sensasi petualangan melintasi perut bumi yang eksotis dan mendebarkan, dan penelusuran sejarah budaya manusia yang pernah tinggal di dalam gua dan ceruk di Bukit Bangkai ini. Kedua skema perjalanan wisata ini tetap memerlukan pemandu wisata yang mumpuni, sehingga perjalanan wisata tersebut dapat berjalan lancar dan selamat, serta para pengunjung bisa puas menikmati perjalanannya dan mendapatkan tambahan wawasan sejarah budaya yang diinginkannya. Oleh karena itu, perlu perencanaan pengembangan wisata yang baik dan terpadu, yang melibatkan banyak instansi terkait, para pakar ilmu pengetahuan dan budaya, LSM, dan masyarakat setempat.

\section{Ancaman Nyata Terhadap Kawasan Karst di Kecamatan Mantewe}

Tampaknya potensi kawasan karst di Kecamatan Mantewe memang menawarkan sesuatu yang bermanfaat baik bagi kehidupan manusia pada masa lalu maupun sekarang. Pada masa lalu, manusia prasejarah justru arif untuk mencari tempat tinggal yang nyaman untuk kelangsungan kehidupan mereka. Keperluan akan tempat tinggal ini tampaknya bergayung sambut dengan kemurahan lingkungan alam. Lingkungan karst menyediakan banyak sekali gua dan ceruk yang bisa dijadikan tempat tinggal tanpa perlu membuatnya. Manusia prasejarah bisa langsung menggunakan gua atau ceruk payung yang ada, selama kondisinya memang memungkinkan dan dirasa nyaman tinggal di dalamnya. Sekarang, potensi gua dan ceruk itu 
juga menawarkan keuntungan yang sedikit berbeda bagi manusia yang tinggal di sekitarnya. Pengetahuan tentang adanya kotoran kelelawar (guano) yang bisa dijadikan pupuk tanaman alamiah dan murah, merupakan godaan yang sangat besar bagi kelompok petani.

Pengambilan guano di gua-gua dan ceruk yang ada di Kecamatan Mantewe mungkin sudah lama terjadi, karena masyarakat di sekitar gunung atau bukit karst biasanya berprofesi sebagai petani atau peladang. Mereka membuka ladang atau sawah di sekitar gunung karst, yang selalu menyediakan sumber air yang sangat diperlukan bagi pertumbuhan tanaman yang mereka kelola. Sumber air merupakan salah satu potensi yang perlu diperhatikan dari keberadaan gunung dan bukit karst bagi kehidupan masyarakat di sekitarnya. Kawasan karst baik itu gunung atau bukit yang berdiri sendiri atau pun berderet panjang sebagai sebuah pegunungan, mempunyai keistimewaan yang sangat penting yaitu sebagai penyimpan air bawah tanah.

Ancaman lain terhadap kelestarian kawasan karst di Kecamatan Mantewe adalah kegiatan penambangan batubara. Penambangan batubara di wilayah Kecamatan Mantewe merupakan penyumbang dana terbesar bagi pembangunan sektor ekonomi di Kabupaten Tanah Bumbu pada umumnya. Hampir semua areal pegunungan dan perbukitan di Kecamatan Mantewe, diduga mempunyai kandungan batubara di lapisan tanah di bawahnya yang menjadi incaran penambang batubara.

Ancaman yang ketiga terhadap kelestarian kawasan karst di Kecamatan Mantewe muncul dari kegiatan penambangan batu kapur. Kegiatan penambangan batu kapur ini terjadi pada hampir semua kawasan karst yang ada di Kalimantan Selatan. Penambangan batu kapur ini digunakan untuk memenuhi keperluan akan bahan material pembuatan jalan, pembangunan gedung, dan rumah penduduk. Ketiga ancaman ini yang menjadikan kegiatan penelitian arkeologi prasejarah di kawasan karst di Kecamatan Mantewe menjadi sangat penting untuk dilakukan. Kegiatan penelitian arkeologi prasejarah di areal ini berkejaran dengan waktu karena progres kegiatan penambangan yang sangat pesat.
Ancaman yang paling besar untuk kelestarian kawasan karst adalah eksploitasi material batu kapur. Penambangan ini akhirnya menguras batu kapur di banyak gunung dan bukit karst. Dalam Pedoman Pengelolaan Kawasan Karst yang dikeluarkan oleh Menteri Energi dan Sumber Daya Mineral dengan nomor: 1456 K/20/MEM/ 2000, pasal 2 ayat 1, dikatakan bahwa pengelolaan karst bertujuan mengoptimalkan pemanfaatan kawasan karst, guna menunjang pembangunan berkelanjutan dan berwawasan lingkungan (Departemen Energi dan Sumber Daya Mineral 2000). Kemudian dalam pasal 2 ayat 2, dikatakan bahwa sasaran pengelolaan kawasan karst adalah melestarikan keunikan dan kelangkaan bentukan alam yang ada di kawasan karst. Selanjutnya dalam pasal 3 dikatakan bahwa nilai arkeologi merupakan salah satu nilai strategis yang terkandung dalam kawasan karst. Secara lengkap petikan pasal 3 adalah :

" ... kawasan karst mempunyai beberapa nilai yang sifatnya strategis, yaitu nilai ekonomi, berkaitan dengan usaha pertanian, kehutanan, pertambangan, pengelolaan air dan pariwisata; nilai ilmiah, berkaitan dengan ilmu-ilmu kebumian, speleologi (ilmu tentang perguaan), biologi, arkeologi, dan paleontologi; nilai kemanusiaan, berkaitan dengan keindahan, rekreasi, pendidikan, unsur spiritual, agama dan kepercayaan."

Berdasarkan Kepmen tersebut, setiap pemerintah kabupaten/kota dapat melakukan penetapan klasifikasi kawasan karst yang ada di masing-masing wilayahnya. Penetapan klasifikasi kawasan karst harus dilakukan sebagai dasar bagi pemanfaatan dan pengelolaan sumber daya alam dan budaya yang ada di dalamnya. Penetapan ini dapat dilakukan oleh bupati/walikota berdasarkan hasil kajian tim pelaksana di lapangan. Aturan mainnya menyebutkan bahwa kawasan karst diatur dan dibagi menjadi tiga kelas, yaitu: kelas I, kelas II, dan Kelas III.

Masing-masing kelas mempunyai spesifikasi dan cara pengelolaan yang berbeda. Pasal 13 menyebutkan bahwa kawasan karst kelas I adalah kawasan lindung sumber daya alam. Semua pemanfaatan dan perlindungannya harus sesuai dengan peraturan perundang-undangan yang berlaku. Sementara untuk kawasan karst kelas II, dapat dilakukan kegiatan penambangan dengan 
syarat harus dilengkapi dengan studi lingkungan (AMDAL atau UKL dan UPL), sesuai dengan ketentuan peraturan perundang-undangan yang berlaku. Di dalam kawasan karst kelas III, dapat dilakukan kegiatan-kegiatan penambangan sesuai dengan ketentuan perundang-undangan yang berlaku.

Dengan pedoman di atas, kita dapat merencanakan program pengelolaan kawasan karst beserta data sejarah budaya yang ada di dalamnya dengan baik dan benar. Selanjutnya proses perencanaan pengelolaan sumber daya budaya yang terdapat di dalam kawasan karst tersebut menjadi perhatian berikutnya. Perencanaan pengelolaan ini memerlukan dukungan semua lapisan masyarakat dan juga para pakar terkait, agar dimanfaatkan untuk sebesar-besarnya kemakmuran masyarakat yang ada di sekitarnya.

\section{PENUTUP}

Dari hasil pemaparan di atas, dapat disimpulkan bahwa di Kabupaten Tanah Bumbu, terutama di Kecamatan Mantewe memiliki sumberdaya arkeologi yang sangat penting bagi perkembangan ilmu pengetahuan dan sejarah budaya. Sumber daya arkeologi tersebut berada pada gua-gua hunian prasejarah pada kawasan karst yang ada di wilayah Kecamatan Mantewe yang tersebar pada beberapa desa. Beberapa situs gua hunian yang sudah diteliti oleh Balai Arkeologi Banjarmasin, yaitu Gua Sugung (Desa Mantewe), Gua Payung (Desa Bulurejo), Liang Ulin (Desa Sukadamai), dan Gua-gua yang ada di Bukit Bangkai (Desa Dukuhrejo). Kegiatan penelitian arkeologi yang dilakukan Balai Arkeologi Banjarmasin belum menjangkau semua kawasan karst yang ada di Kecamatan Mantewe. Luasnya kawasan karst Mantewe merupakan satu tantangan tersendiri bagi kita semua, dan kegiatan penelitian arkeologi akan terus berlangsung sampai dengan waktu tak terbatas pada areal ini. Situs-situs di atas dapat menjadi situs arkeologi prasejarah utama dan unggulan, sebagai dasar untuk merencanakan pengelolaan dan pemanfaatan kawasan karst di masa yang akan datang.

Situs arkeologi prasejarah yang paling potensial ada di Bukit Bangkai, Desa Dukuhrejo, Kecamatan Mantewe. Sebuah bukit karst yang berdiri gagah jauh dari pemukiman penduduk Desa Dukuhrejo ini menyimpan situs-situs hunian prasejarah yang sangat penting bagi perkembangan ilmu pengetahuan dan sejarah budaya masyarakat di Tanah Bumbu serta Kalimantan Selatan. Di Bukit Bangkai 10.000 tahun lalu diperkirakan sudah ada kelompok manusia yang tinggal di dalam gua, dengan mengembangkan sistem perburuan dan meramu makanan yang efektif. Mereka berkembang dan bertahan hidup di sini sampai sekitar 3.000 tahun lalu. Ke depannya, kita berharap menemukan situs lainnya mengingat kawasan karst Mantewe belum semuanya diteliti dengan tuntas. Paling tidak kita sudah mempunyai modal besar untuk mengembangkan studi arkeologi prasejarah di Kabupaten Tanah Bumbu.

Potensi situs arkeologi prasejarah di kawasan karst Mantewe sangat besar dan masih memerlukan serangkaian kegiatan penelitian yang berkelanjutan. Kegiatan penelitian ini dapat berlangsung dengan syarat kelestarian lingkungan kawasan karst Mantewe terjaga dengan baik. Oleh karena itu, Pemerintah Kabupaten Tanah Bumbu dapat melakukan klasifikasi dan penetapan kawasan karst yang ada di wilayah Kabupaten Tanah Bumbu. Klasifikasi dan penetapan kawasan karst ini merupakan tahapan yang sangat krusial bagi upaya pelestarian dan pengamanan aset sejarah budaya yang ada di kawasan karst Mantewe supaya tidak terganggu oleh berbagai ancaman dari luar.

Ancaman terhadap situs prasejarah di wilayah pegunungan karst adalah berupa penggalian guano dan penambangan batu kapur yang sudah dilakukan oleh penduduk dan perusahaan, serta adanya kandungan batu bara di bawah situs yang menjadi incaran pegusaha tambang batu bara. Bila kegiatan eksplorasi itu terus berlangsung, maka situs akan rusak, bahkan hilang sama sekali. 


\section{DAFTAR PUSTAKA}

Crabtree, Don E. 1972. An Introduction to Flintworking. Idaho: Occasional Papers of Museum Idaho State University.

Deetz, James F. 1967. Invitation to Archaeology. New York: The Natural History Press.

Fajari, Nia Marniati Etie dan Vida Pervaya R. Kusmartono, 2013. "The Excavation of Gua Payung in South Kalimantan, Indonesia". HIm. 20-23 dalam Bulletin of the Indo-Pacific Prehistory Archaeology Vol. 33.

Handini, Retno dan Harry Widianto. 1998. "Song Keplek: Okupasi Intensif Manusia Pada Periode Pasca-Plestosen di Gunung Sewu". Berkala Arkeologi XIX (1): 72-91.

Pemerintah Republik Indonesia. 2000. Keputusan Menteri Energi dan Sumber Daya Mineral Nomor: $1456 \mathrm{~K} / 20 / \mathrm{MEM} / 2000$ tentang Pedoman Pengelolaan Kawasan karst. Jakarta: Departemen Energi dan Sumber Daya Mineral.

Oktrivia, Ulce, Imam Hindarto, dan Eko Herwanto. 2013. "Potensi Arkeologi di sekitar Bukit Ulin, Kecamatan Mantewe, Kabupaten Tanah Bumbu". Laporan Penelitian Arkeologi. Banjarbaru: Balai Arkeologi Banjarmasi.

Semenov, S.A. 1964. Prehistoric Technology. London: Cory and Mckay Ltd.

Sugiyanto, Bambang. 2009. "Hunian Gua Prasejarah di Kecamatan Mantewe". Berita Penelitian Arkeologi 3 (1): 1-23. - 2010. "Penelitian Situs Prasejarah Gua Bangkai, Kecamatan Mantewe,
Kabupaten Tanah Bumbu (Tahap III)". Laporan Penelitian Arkeologi. Banjarbaru: Balai Arkeologi Banjarmasin. - 2011. "Gua-gua Budaya di Kalimantan Selatan, Bagaimana Mengelolanya?" HIm. 110-123 dalam Arkeologi dan Sumber Daya Budaya di Kalimantan: Masalah dan Apresiasi, diedit oleh H.S. Ahimsa-Putra. Banjarbaru: IAAI Komda Kalimantan. -2012. "Penelitian Prasejarah Liang Bangkai, Kecamatan Mantewe, Kabupaten Tanah Bumbu (Tahap IV)". Laporan Penelitian Arkeologi. Banjarbaru: Balai Arkeologi Banjarmasin.

Sugiyanto, Bambang, Jatmiko, dan Yuka Nurtanti, 2013. "Survei dan Ekskavasi Situs Liang Bangkai, Desa Dukuhrejo, Kecamatan Mantewe, Kabupaten Tanah Bumbu, Kalimantan Selatan (Tahap V)". Laporan Penelitian Arkeologi. Banjarbaru: Balai Arkeologi Banjarmasin.

Sugiyanto, Bambang, Jatmiko, Nugroho Nur Susanto, Imam Hindarto, Eko Herwanto, dan Yuka Nurtanti, 2014. "Penelitian Guagua Hunian Prasejarah di Bukit Bangkai, Kecamatan Mantewe, Kabupaten Tanah Bumbu (Tahap VI)". Laporan Penelitian Arkeologi. Banjarbaru: Balai Arkeologi Banjarmasin.

Widianto, Harry dan Retno Handini, 2003. "Karakter Budaya Prasejarah di Situs Gua Babi: Mekanisme Hunian Gua Prasejarah Pasca-Plestosen". Berita Penelitian Arkeologi 12: 1-91. 